\title{
The Effects of Different Oxytetracycline and Copper Treatments on the Performance of Anaerobic Digesters and the Dynamics of Bacterial Communities
}

\author{
Yun Zhang, ${ }^{1}$ Xin Ke, ${ }^{2}$ Wei Sun, ${ }^{2}$ Guangcai Zhang ${ }^{D},{ }^{1}$ \\ Xiaodan Gao, ${ }^{1}$ Haijun Zhang, ${ }^{2}$ and Weiyun Wang $\mathbb{D}^{2}$ \\ ${ }^{1}$ Northeast Key Laboratory of Arable Land Conservation and Improvement, Ministry of Agriculture, \\ National Engineering Laboratory for Efficient Utilization of Soil and Fertilizer Resources, College of Land and Environment, \\ Shenyang Agricultural University, Shenyang 110866, China \\ ${ }^{2}$ College of Energy and Environment, Shenyang Aerospace University, Shenyang 110136, China
}

Correspondence should be addressed to Guangcai Zhang; guangcaizhang@syau.edu.cn and Weiyun Wang; cathywwy@sau.edu.cn Received 24 October 2017; Revised 27 April 2018; Accepted 21 May 2018; Published 5 July 2018

Academic Editor: Zhang Lei

Copyright (C) 2018 Yun Zhang et al. This is an open access article distributed under the Creative Commons Attribution License, which permits unrestricted use, distribution, and reproduction in any medium, provided the original work is properly cited.

\begin{abstract}
Oxytetracycline and copper are the common residues in animal manures. Meanwhile, anaerobic digestion is considered as a clean biotechnology for the disposal of animal manures. In this paper, the performance of anaerobic digesters and the dynamics of bacterial communities under the different treatments of oxytetracycline and copper were discussed. The parameters of methane production and $\mathrm{pH}$ values were studied to reflect the performance of anaerobic digester. Results showed that the changes of methane production and $\mathrm{pH}$ values were not obvious compared with the control. This means that the treatments of oxytetracycline and copper almost have no effects on the performance of anaerobic digesters. This phenomenon might be due to the chelation reaction between oxytetracycline and copper. This chelation reaction might reduce the toxicity of oxytetracycline. The study on the dynamics of bacterial communities was based on the polymerase chain reaction-denaturing gradient gel electrophoresis (PCR-DGGE) method. Results indicated that the bacterial communities had significant differences under the different treatments of oxytetracycline and copper. Uncultured Bacteroidetes bacterium (CU922272.1) and uncultured Bacteroidetes bacterium (AB780945.1) showed adaptability to the different treatments of oxytetracycline and copper and were the dominant bacterial communities.
\end{abstract}

\section{Introduction}

With the development of livestock, the residual antibiotics and heavy metals in animal manure have attracted more and more world-wide attention. This residual phenomenon is due to the low bioavailability of antibiotics and heavy metals which are widely added to the feeds in order to control diseases and enhance the growth of livestock animals [14]. Heuer et al. [5] found that $30-90 \%$ of the antibiotics as feeding additives were excreted through urine and manures. The residual metals in manure were also considerable $[6,7]$. Oxytetracycline and copper are the common residues in animal manures. It was found that the residual oxytetracycline in cow manure ranged from $0.32 \mathrm{mg} / \mathrm{kg}$ to $59.59 \mathrm{mg} / \mathrm{kg}$ [8].
The residual copper could reach up to $481.5 \mathrm{mg} / \mathrm{kg}$ in cattle manures [9]. These residual antibiotics and heavy metals can cause the potential threats to environment. Therefore, it is necessary to find appropriate methods to solve the problems of residual oxytetracycline and copper in animal manure.

Animal manures belong to the organic wastes. The common methods of the disposal of manure include aerobic composting and anaerobic digestion [10-12]. Compared to other methods, anaerobic digestion belongs to a clean biotechnology which can produce biogas [13]. Meanwhile, the use of biogas can reduce the consumption of fossil fuels and the emissions of greenhouse gases $[14,15]$. The residual digestate after anaerobic digestion can be used as an improved fertilizer [16]. 
TABLE 1: Different treatments of oxytetracycline and copper in the laboratory-scale anaerobic digesters.

\begin{tabular}{lcc}
\hline Treatments & $\begin{array}{c}\text { Oxytetracycline } \\
\text { dry weight }(\mathrm{mg} / \mathrm{kg})\end{array}$ & $\begin{array}{c}\text { Copper }(\text { dose as CuSO } \\
\text { dry weight }(\mathrm{mg} / \mathrm{kg})\end{array}$ \\
\hline A1 & 20 & 100 \\
$\mathrm{~A} 2$ & 20 & 200 \\
$\mathrm{~A} 3$ & 20 & 300 \\
$\mathrm{~B} 1$ & 50 & 100 \\
$\mathrm{~B} 2$ & 50 & 200 \\
$\mathrm{~B} 3$ & 50 & 300 \\
C1 & 100 & 100 \\
C2 & 100 & 200 \\
C3 & 100 & 300 \\
Control & 0 & 0 \\
\hline
\end{tabular}

The performance of anaerobic digester can be reflected by methane production and $\mathrm{pH}$ values $[17,18]$. Furthermore, anaerobic digestion is considered to be a biological process which involves many classes of bacteria. It consists of four stages: hydrolysis, acidogenesis, acetogenesis, and methanogenesis $[19,20]$. Bacterial communities show dynamics during the process of anaerobic digestion. Bouallagui et al. [21] studied the dynamics of bacterial communities in a two-phase anaerobic bioreactor. They found that the species composition of bacterial communities had very significant changes during the process of anaerobic digestion. Patil et al. [22] studied the dynamics of microbial community via polymerase chain reaction-denaturing gradient gel electrophoresis (PCR-DGGE) and found that Firmicutes and uncultured bacteria were the dominant genera in the mesophilic digesters treating with piggery wastewater. However, there is still short of the study on the dynamics of bacterial communities under the treatments of oxytetracycline and copper during anaerobic digestion.

The objectives of this study were to evaluate the performance of anaerobic digesters and discuss the dynamics of bacterial communities under the treatments of oxytetracycline and copper during the anaerobic digestion of cow manure. Methane production and $\mathrm{pH}$ values were measured and analyzed to reflect the performance of anaerobic digestion. Furthermore, the PCR-DGGE method was used to discuss the dynamics of bacterial communities.

\section{Materials and Methods}

2.1. Experimental Set-Up and Analytical Methods. Cow manure samples were taken from the surrounding countryside Shenyang City, China. Then the samples were stored in a refrigerator at $4^{\circ} \mathrm{C}$ before used. The physical and chemical properties of samples were as follows: total solids, $25.67 \%$; $\mathrm{pH}$ value, 8.26; volatile organic acids, $878.4 \mathrm{mg} \mathrm{l}^{-1}$; and organic carbon, $42.75 \%$. Laboratory-scale anaerobic digesters (1 L) were prepared. Then each digester was added with $200 \mathrm{~g}$ cow manure. Different amounts of oxytetracycline and copper (dose as $\mathrm{CuSO}_{4}$ ) were added to each digester (Table 1). In this experiment, the fermentation broth of digested cow manure was used as the inoculum. Each anaerobic digester was inoculated with $200 \mathrm{ml}$ inoculum, then continuously stirred, and maintained at a mesophilic condition of $37^{\circ} \mathrm{C}$ in a water bath. All the experiments were performed in triplicate. Methane production was measured by gas chromatography (GC-14B, Shimadzu, Japan). The pH values were determined using a hand-held $\mathrm{pH}$ meter.

2.2. DNA Extraction and PCR-DGGE. Total genomic DNA of manure samples was extracted on days 1,15 , and 50 , respectively. In this experiment, the primers $341 \mathrm{~F}$ with $40 \mathrm{bp}$ GCclamps and 907R were used for the polymerase chain reaction amplification [23]. The operations of DNA extraction and PCR-DGGE were carried out as the previous study [24], but with some modifications that the electrophoresis was performed in a $7 \mathrm{~L} 1 \times$ TAE buffer at $60^{\circ} \mathrm{C}$ for $6 \mathrm{~h}$ at $180 \mathrm{~V}$ in this experiment.

2.3. Sequencing and Phylogenetic Analysis. The selected DGGE bands were reamplified and electrophoresed to confirm the mobility and then transported to Beijing Huada Gene Company (Beijing, China) for sequencing. Through the CLUSTAL X and MEGA 4.0, the phylogenetic tree was built via the neighbor-joining method [25].

2.4. Nucleotide Sequence Accession Numbers. Nucleotide sequences were deposited in the NCBI nucleotide sequence databases to get the accession numbers: KM491540KM491545.

\section{Results and Discussion}

\subsection{The Performance of Anaerobic Digesters}

3.1.1. Methane Production. Methane production under the different treatments of oxytetracycline and copper is present in Figure 1. The highest methane production under treatments A1, A2, A3, B1, B3, B4, C1, C2, C3, and the control was $331.9 \mathrm{ml}$ (day 15), $399.5 \mathrm{ml}$ (day 10), $556.2 \mathrm{ml}$ (day 10), $371.7 \mathrm{ml}$ (day 15), $510.5 \mathrm{ml}$ (day 10), $360.5 \mathrm{ml}$ (day 10), $399.5 \mathrm{ml}$ (day 10), $460.3 \mathrm{ml}$ (day 10), $516.8 \mathrm{ml}$ (day 10), 


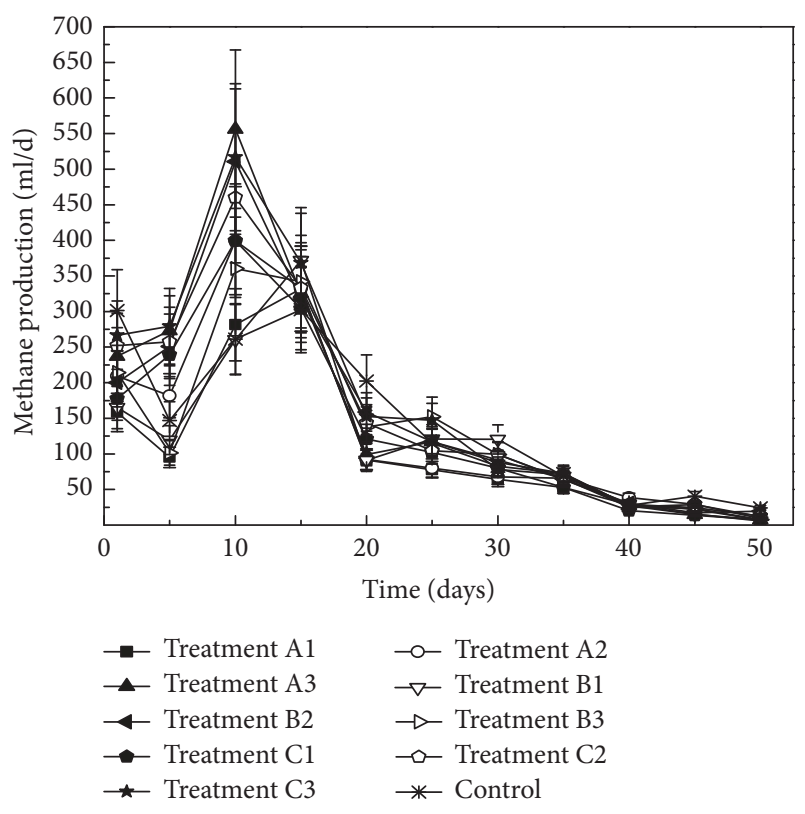

FIGURE 1: Variations of methane production with time under different oxytetracycline and copper treatments.

and $302.7 \mathrm{ml}$ (day 15), respectively. At the first five days, the process of anaerobic digestion was not stable. Then the methane production increased until the 10th day. Compared with the control, the curve of methane production had nonsignificant differences after the 25th day. This might be caused by the chelation reaction between oxytetracycline and copper. Pouliquen and Le Bris [26] found that oxytetracycline was likely to form complexes with mineral cations. Moreover, Hassan et al. [27] reported that oxytetracycline could form the copper-oxytetracycline chelates. Previous studies had found that oxytetracycline had inhibition on methane production during the anaerobic digestion $[28,29]$. However, the chelation reaction between oxytetracycline and copper might reduce the toxicity of oxytetracycline. Therefore, the treatments of oxytetracycline and copper had little effect on the methane production.

3.1.2. The $\mathrm{pH}$ Values. The changes of $\mathrm{pH}$ values during the anaerobic digestion are shown in Figure 2. The $\mathrm{pH}$ values under all treatments ranged from 6.61 to 7.31 . This range belongs to the optimal $\mathrm{pH}$ values to produce maximal biogas yield. Throughout the process of anaerobic digestion, $\mathrm{pH}$ values gradually increased. This might be due to the continuous stirring which could make cow manure continued dissolution. The highest $\mathrm{pH}$ values which were all present at the end of the anaerobic digestion were 7.21 (treatment A1), 7.24 (treatment A2), 7.25 (treatment A3), 7.22 (treatment B1), 7.31 (treatment B2), 7.23 (treatment B3), 7.18 (treatment $\mathrm{C} 1$ ), 7.28 (treatment C2), 7.27 (treatment C3), and 7.14 (control). As is shown in Figure 2, the $\mathrm{pH}$ values under all treatments did not present significant differences compared with the control. This means that the treatments of oxytetracycline and copper almost have no significant effects on the $\mathrm{pH}$ values during the process of anaerobic digestion of cow manure.

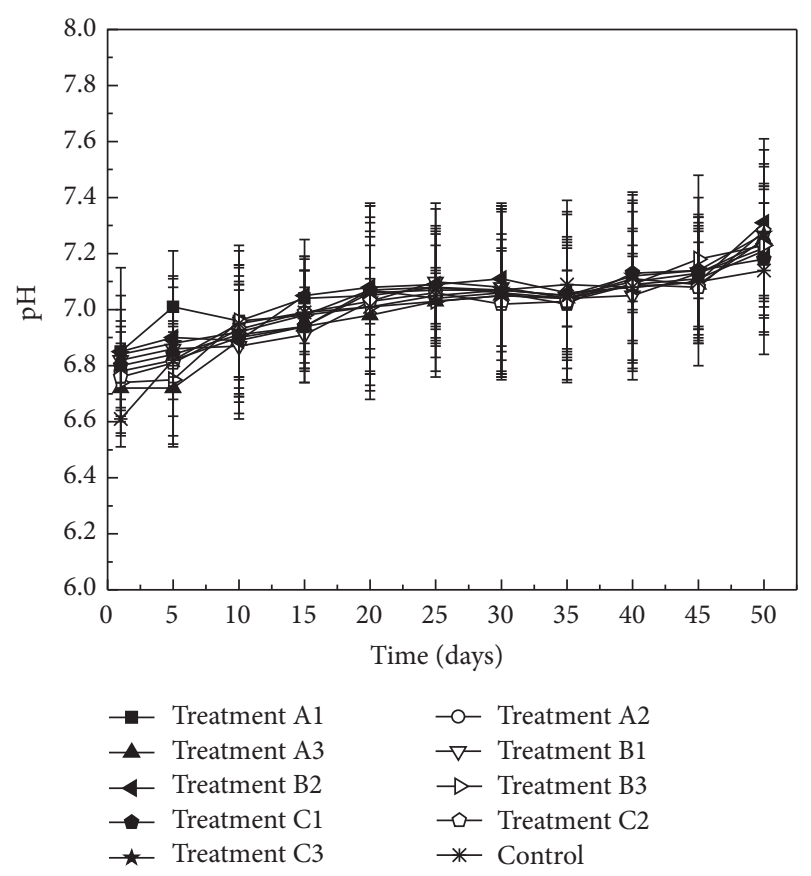

FIGURE 2: Variations of $\mathrm{pH}$ value with time under different oxytetracycline and copper treatments.

3.2. Dynamics of Bacterial Communities. Dynamics of bacterial communities under the different treatments of oxytetracycline and copper are present via the DGGE fingerprints in Figure 3. The DGGE band patterns showed significant differences and clear changes under different treatments. Bands $\mathrm{H} 1, \mathrm{H} 2$, and $\mathrm{H} 4$ were detected at day 10 . However, they disappeared at day 50 . Band $\mathrm{H} 3$ could only be observed at day 50. Bands $\mathrm{H} 5$ and $\mathrm{H} 6$ were present under all the treatments of oxytetracycline and copper during the whole process of anaerobic digestion. They were the dominant bacterial communities.

Although band H5 was not shown at the control DGGE bands of day 1, it appeared at the control DGGE bands of day 10 and day 50. In contrast, band H6 was shown at all DGGE bands. This indicated that band $\mathrm{H} 6$ seemed to play as the functional bacteria. Through the sequence similarity analysis by the BLAST program, these six bacterial sequences were conducted by homology comparison (Table 2). The phylogenetic tree was established in Figure 4. Results showed that Band $\mathrm{H} 2$ had $98 \%$ similarity to uncultured bacterium (KJ853330.1). Band 4 was closely related to Acidovorax sp. (JQ912595.1). Hoshino et al. [30] found that Acidovorax sp. played an important role in denitrification. Band 3 had high similarity to uncultured Cytophagales bacterium (HQ692035.1). Band H1 shared 95\% similarity with Porphyromonadaceae bacterium (HQ133063.1). These three kinds of bacteria all could be detected in the anaerobic digestion [31, 32]. Band $\mathrm{H} 5$ had $99 \%$ similarity to uncultured Bacteroidetes bacterium (CU922272.1). Band H6 was closely related to uncultured Bacteroidetes bacterium (AB780945.1). Riviere et al. [33] reported that uncultured Bacteroidetes bacterium (CU922272.1) existed in the mesophilic anaerobic digestion 
TABLE 2: Closest relatives of the bacterial 16S-rRNA gene sequences.

\begin{tabular}{lccc}
\hline DGGE band & Closest GenBank Relative (accession number) & $\begin{array}{c}\text { Sequence } \\
\text { homology (\%) }\end{array}$ & $\begin{array}{c}\text { Accession } \\
\text { Number }\end{array}$ \\
\hline H1 & Porphyromonadaceae bacterium (HQ133063.1) & $95 \%$ & KM491540 \\
H2 & Uncultured bacterium (KJ853330.1) & $98 \%$ & KM491541 \\
H3 & Uncultured Cytophagales bacterium (HQ692035.1) & $90 \%$ & KM491542 \\
H4 & Acidovorax sp. (JQ912595.1) & $99 \%$ & KM491543 \\
H5 & Uncultured Bacteroidetes bacterium (CU922272.1) & $99 \%$ & KM491544 \\
H6 & Uncultured Bacteroidetes bacterium (AB780945.1) & $98 \%$ & KM491545 \\
\hline
\end{tabular}

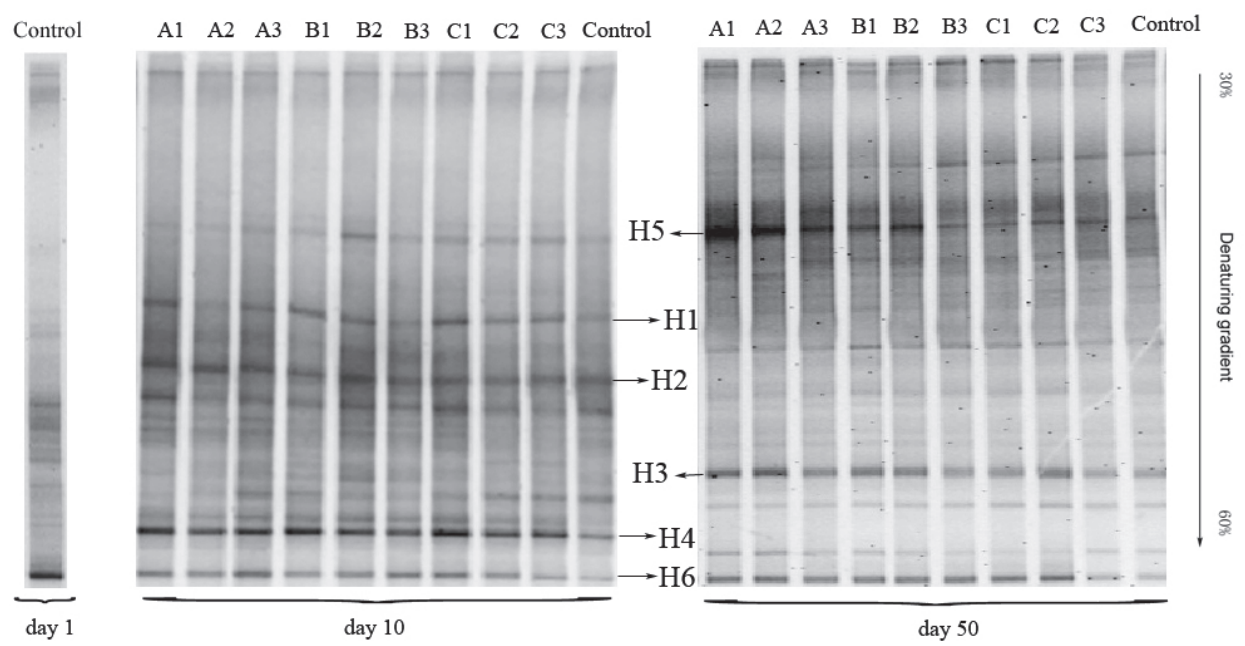

FIGURE 3: Denaturing gradient gel electrophoresis (DGGE) fingerprints of bacterial 16S-rRNA gene fragments of cow manure samples under different oxytetracycline and copper treatments at day 1, day 10, and day 50 .

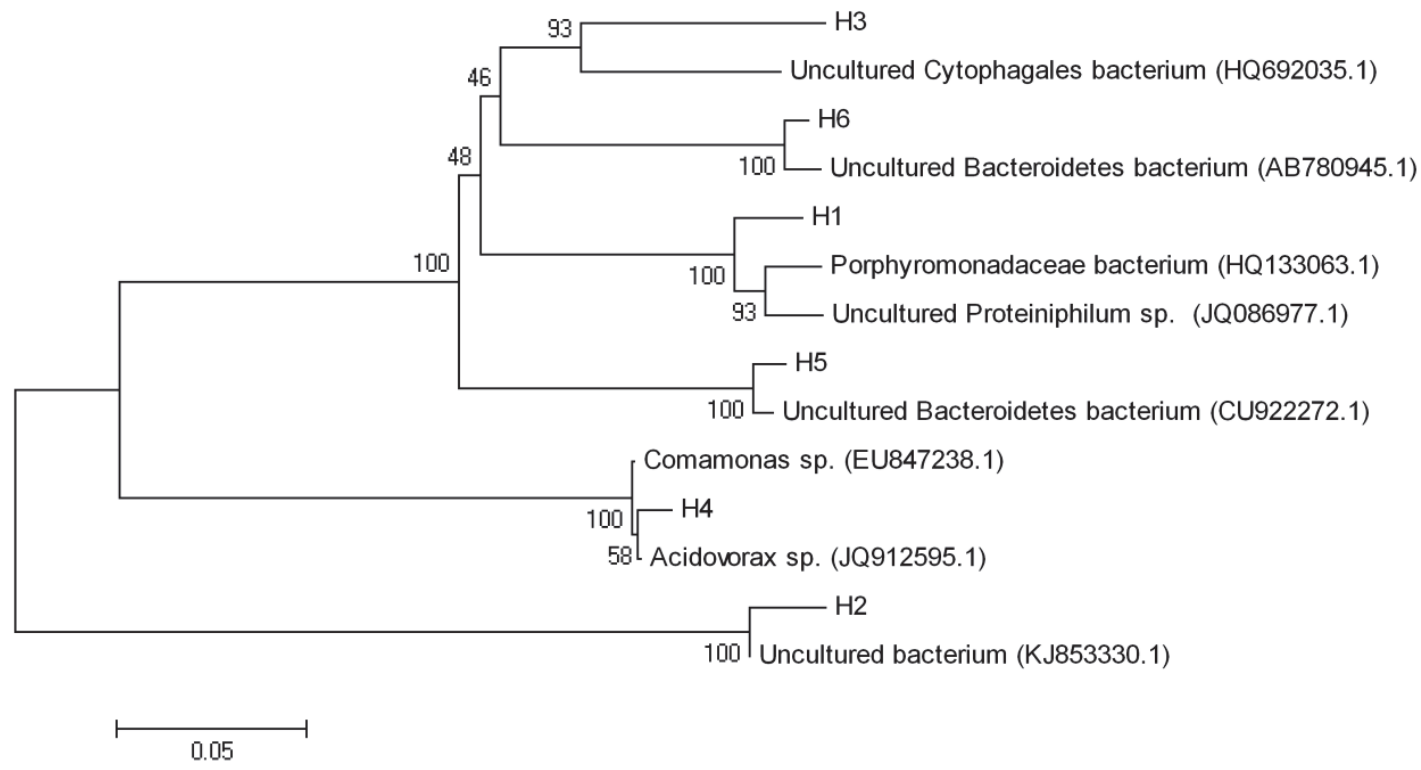

FIgURE 4: Phylogenetic tree of the bacterial 16S-rRNA gene sequences compared with known sequences from Genbank. 
of municipal sewage sludge. Uncultured Bacteroidetes bacterium (AB780945.1) could be found in a full-scale mesophilic anaerobic completely stirred tank reactor during the anaerobic digestion of untreated corn straw [34].

In this experiment, it could be concluded that uncultured Bacteroidetes bacterium (CU922272.1) and uncultured Bacteroidetes bacterium (AB780945.1) showed adaptability to the different treatments of oxytetracycline and copper and were the dominant bacterial communities during the anaerobic digestion under the treatments of oxytetracycline and copper.

\section{Conclusions}

This study discussed the performance of anaerobic digesters and the dynamics of bacterial communities under different treatments of oxytetracycline and copper. Results indicated that methane production and $\mathrm{pH}$ values were hardly affected compared with the control. This might be due to the chelation reaction between oxytetracycline and copper. The reaction might reduce the toxicity of oxytetracycline. Meanwhile, uncultured Bacteroidetes bacterium (CU922272.1) and uncultured Bacteroidetes bacterium (AB780945.1) were the dominant bacterial communities during the anaerobic digestion under the treatments of oxytetracycline and copper. This research can help to optimize the performance of anaerobic digestion and the structure of bacterial community for increasing the biogas production and reducing the pollution of residues.

\section{Conflicts of Interest}

The authors declare that there are no conflicts of interest.

\section{Acknowledgments}

This study was supported by Agro-Scientific Research in the Public Interest (201503118-10), National Natural Science Foundation of China (41601230), and Postdoctoral Science Foundation (2017M611265).

\section{References}

[1] M.-O. Aust, F. Godlinski, G. R. Travis et al., "Distribution of sulfamethazine, chlortetracycline and tylosin in manure and soil of Canadian feedlots after subtherapeutic use in cattle," Environmental Pollution, vol. 156, no. 3, pp. 1243-1251, 2008.

[2] N. Kemper, "Veterinary antibiotics in the aquatic and terrestrial environment," Ecological Indicators, vol. 8, no. 1, pp. 1-13, 2008.

[3] A. Bielicka, I. Bojanowska, and A. Wisniewski, "Two faces of chromium-pollutant and bioelement," Polish Journal of Environmental Studies, vol. 14, no. 5, 2005.

[4] Y.-G. Zhu, T. A. Johnson, J.-Q. Su et al., "Diverse and abundant antibiotic resistance genes in Chinese swine farms," Proceedings of the National Acadamy of Sciences of the United States of America, vol. 110, no. 9, pp. 3435-3440, 2013.

[5] H. Heuer, H. Schmitt, and K. Smalla, "Antibiotic resistance gene spread due to manure application on agricultural fields," Current Opinion in Microbiology, vol. 14, no. 3, pp. 236-243, 2011.
[6] J. Dach and D. Starmans, "Heavy metals balance in Polish and Dutch agronomy: Actual state and previsions for the future," Agriculture, Ecosystems \& Environment, vol. 107, no. 4, pp. 309316, 2005.

[7] M. Irshad, A. H. Malik, S. Shaukat, S. Mushtaq, and M. Ashraf, "Characterization of heavy metals in livestock manures," Polish Journal of Environmental Studies, vol. 22, no. 4, pp. 1257-1262, 2013.

[8] L. Zhao, Y. H. Dong, and H. Wang, "Residues of veterinary antibiotics in manures from feedlot livestock in eight provinces of China," Science of the Total Environment, vol. 408, no. 5, pp. 1069-1075, 2010.

[9] X. Ji, Q. Shen, F. Liu et al., "Antibiotic resistance gene abundances associated with antibiotics and heavy metals in animal manures and agricultural soils adjacent to feedlots in Shanghai; China," Journal of Hazardous Materials, vol. 235-236, pp. 178$185,2012$.

[10] A. Khalid, M. Arshad, M. Anjum, T. Mahmood, and L. Dawson, "The anaerobic digestion of solid organic waste," Waste Management, vol. 31, no. 8, pp. 1737-1744, 2011.

[11] R. Yazdani, M. A. Barlaz, D. Augenstein, M. Kayhanian, and G. Tchobanoglous, "Performance evaluation of an anaerobic/ aerobic landfill-based digester using yard waste for energy and compost production," Waste Management, vol. 32, no. 5, pp. 912-919, 2012.

[12] R. Kulcu, "Composting of greenhouse tomato plant residues, wheat straw, and separated dairy manure, and the effect of free air space on the process," Polish Journal of Environmental Studies, vol. 23, no. 4, pp. 1341-1346, 2014.

[13] R. Kothari, V. V. Tyagi, and A. Pathak, "Waste-to-energy: A way from renewable energy sources to sustainable development," Renewable \& Sustainable Energy Reviews, vol. 14, no. 9, pp. 31643170, 2010.

[14] K.-H. Kim, S. A. Jahan, and E. Kabir, "A review of diseases associated with household air pollution due to the use of biomass fuels," Journal of Hazardous Materials, vol. 192, no. 2, pp. 425-431, 2011.

[15] K. Starr, X. Gabarrell, G. Villalba, L. Talens, and L. Lombardi, "Life cycle assessment of biogas upgrading technologies," Waste Management, vol. 32, no. 5, pp. 991-999, 2012.

[16] P. Weiland, "Biogas production: current state and perspectives," Applied Microbiology and Biotechnology, vol. 85, no. 4, pp. 849$860,2010$.

[17] P. Illmer and G. Gstraunthaler, "Effect of seasonal changes in quantities of biowaste on full scale anaerobic digester performance," Waste Management, vol. 29, no. 1, pp. 162-167, 2009.

[18] M. N. Young, R. Krajmalnik-Brown, W. Liu, M. L. Doyle, and B. E. Rittmann, "The role of anaerobic sludge recycle in improving anaerobic digester performance," Bioresource Technology, vol. 128, pp. 731-737, 2013.

[19] P. V. Rao and S. S. Baral, "Attribute based specification, comparison and selection of feed stock for anaerobic digestion using MADM approach," Journal of Hazardous Materials, vol. 186, no. 2-3, pp. 2009-2016, 2011.

[20] F. Xu, J. Shi, W. Lv, Z. Yu, and Y. Li, "Comparison of different liquid anaerobic digestion effluents as inocula and nitrogen sources for solid-state batch anaerobic digestion of corn stover," Waste Management, vol. 33, no. 1, pp. 26-32, 2013.

[21] H. Bouallagui, M. Torrijos, J. J. Godon et al., "Microbial monitoring by molecular tools of a two-phase anaerobic bioreactor treating fruit and vegetable wastes," Biotechnology Letters, vol. 26, no. 10, pp. 857-862, 2004. 
[22] S. S. Patil, M. S. Kumar, and A. S. Ball, "Microbial community dynamics in anaerobic bioreactors and algal tanks treating piggery wastewater," Applied Microbiology and Biotechnology, vol. 87, no. 1, pp. 353-363, 2010.

[23] G. Muyzer, E. C. de Waal, and A. G. Uitterlinden, "Profiling of complex microbial populations by denaturing gradient gel electrophoresis analysis of polymerase chain reaction-amplified genes coding for 16S rRNA," Applied and Environmental Microbiology, vol. 59, no. 3, pp. 695-700, 1993.

[24] X. Ke, C. Wang, R. Li, Y. Zhang, H. Zhang, and S. Gui, "Biomethane production and dynamics of microflora in response to copper treatments during mesophilic anaerobic digestion," Waste Management \& Research, vol. 32, no. 8, pp. 726-732, 2014.

[25] K. Tamura, J. Dudley, M. Nei, and S. Kumar, "MEGA4: molecular evolutionary genetics analysis (MEGA) software version 4.0," Molecular Biology and Evolution, vol. 24, no. 8, pp. 15961599, 2007.

[26] H. Pouliquen and H. Le Bris, "Sorption of oxolinic acid and oxytetracycline to marine sediments," Chemosphere, vol. 33, no. 5, pp. 801-815, 1996.

[27] S. S. M. Hassan, M. M. Amer, and S. A. Ahmed, "Composition and stability constants of iron- and copper-oxytetracycline chelates," Microchimica Acta, vol. 84, no. 3-4, pp. 165-175, 1984.

[28] O. A. Arikan, L. J. Sikora, W. Mulbry, S. U. Khan, C. Rice, and G. D. Foster, "The fate and effect of oxytetracycline during the anaerobic digestion of manure from therapeutically treated calves," Process Biochemistry, vol. 41, no. 7, pp. 1637-1643, 2006.

[29] N. Beneragama, S. A. Lateef, M. Iwasaki, T. Yamashiro, and K. Umetsu, "The combined effect of cefazolin and oxytertracycline on biogas production from thermophilic anaerobic digestion of dairy manure," Bioresource Technology, vol. 133, pp. 23-30, 2013.

[30] T. Hoshino, T. Terahara, S. Tsuneda, A. Hirata, and Y. Inamori, "Molecular analysis of microbial population transition associated with the start of denitrification in a wastewater treatment process," Journal of Applied Microbiology, vol. 99, no. 5, pp. 11651175, 2005.

[31] H. D. Ariesyady, T. Ito, and S. Okabe, "Functional bacterial and archaeal community structures of major trophic groups in a full-scale anaerobic sludge digester," Water Research, vol. 41, no. 7, pp. 1554-1568, 2007.

[32] N. Krakat, S. Schmidt, and P. Scherer, "Potential impact of process parameters upon the bacterial diversity in the mesophilic anaerobic digestion of beet silage," Bioresource Technology, vol. 102, no. 10, pp. 5692-5701, 2011.

[33] D. Rivière, V. Desvignes, E. Pelletier et al., "Towards the definition of a core of microorganisms involved in anaerobic digestion of sludge," The ISME Journal, vol. 3, no. 6, pp. 700714, 2009.

[34] J.-T. Qiao, Y.-L. Qiu, X.-Z. Yuan, X.-S. Shi, X.-H. Xu, and R.-B. Guo, "Molecular characterization of bacterial and archaeal communities in a full-scale anaerobic reactor treating corn straw," Bioresource Technology, vol. 143, pp. 512-518, 2013. 


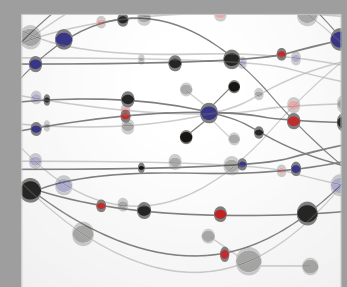

The Scientific World Journal
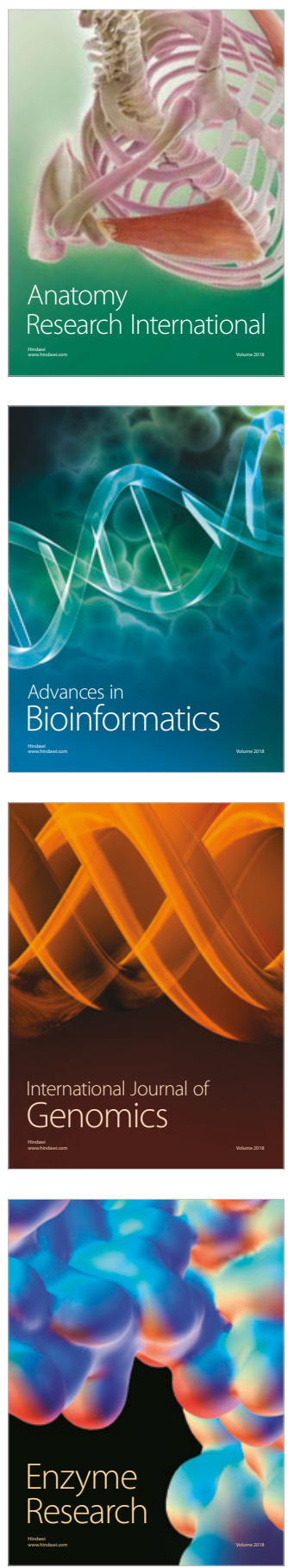
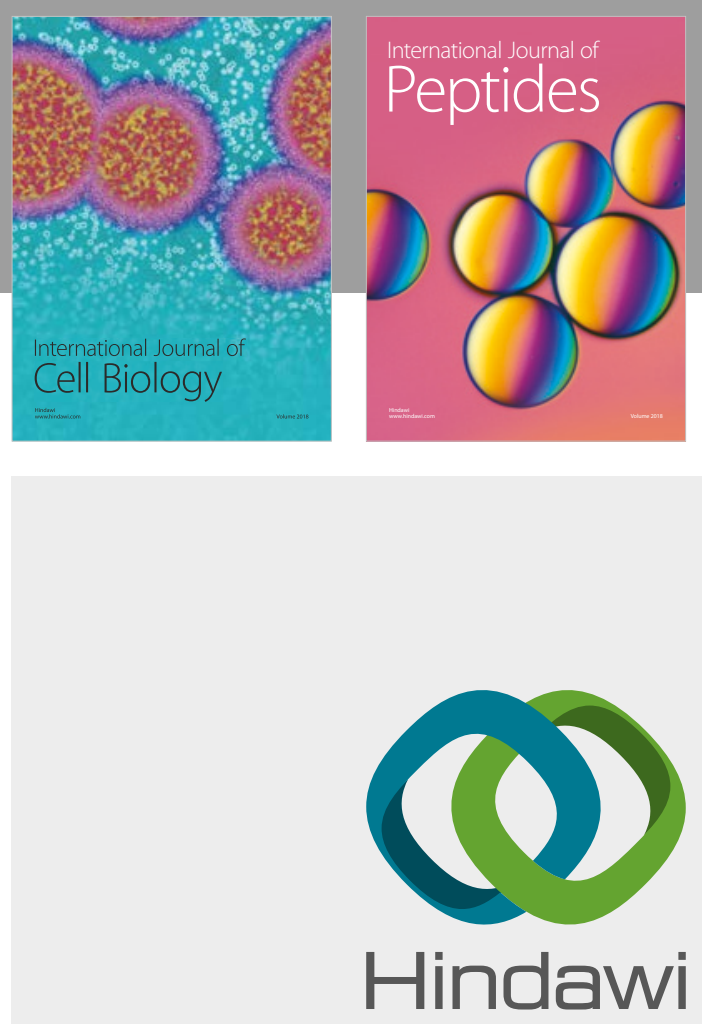

Submit your manuscripts at

www.hindawi.com
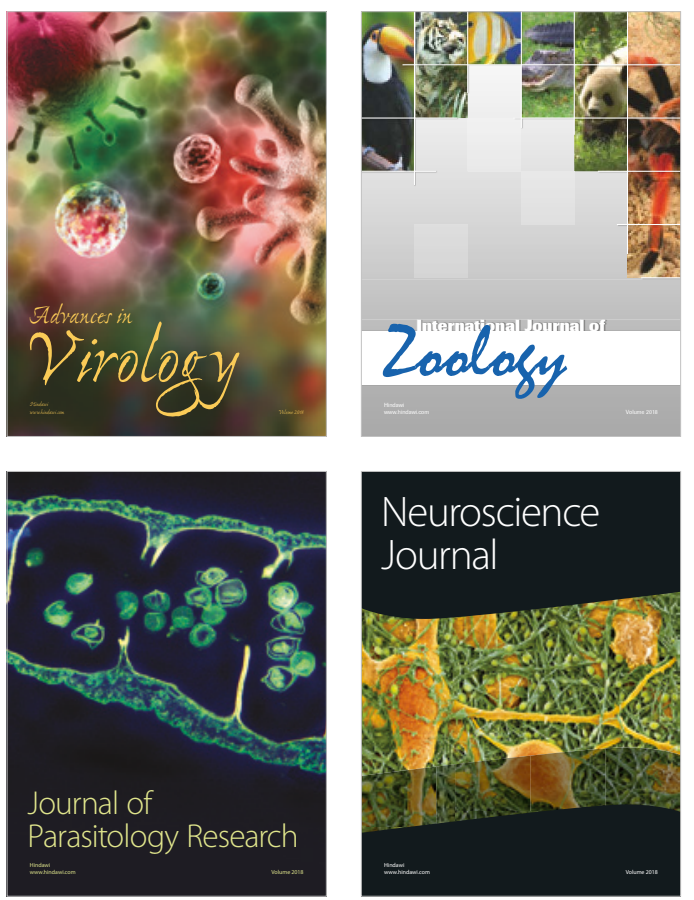
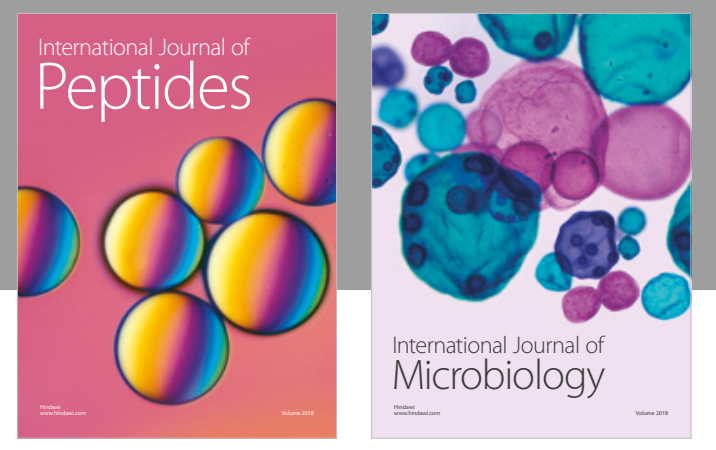

nternational Journal of Microbiology
Journal of
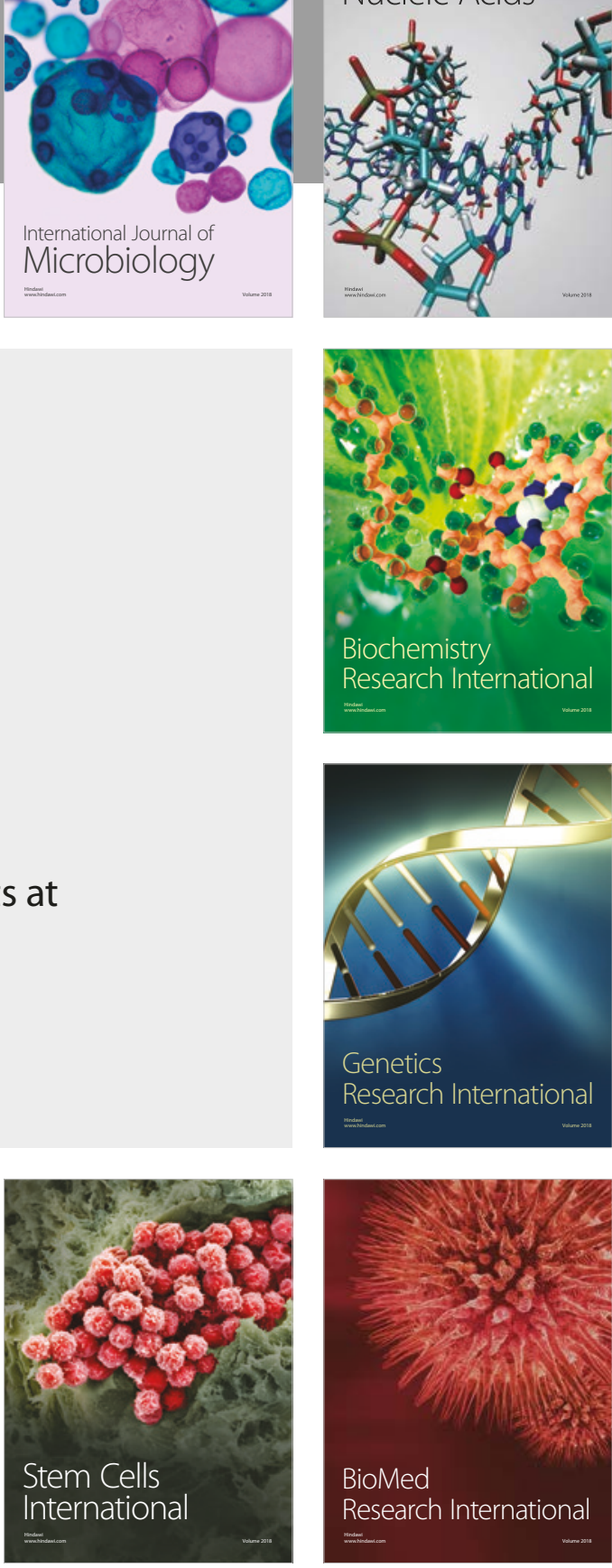
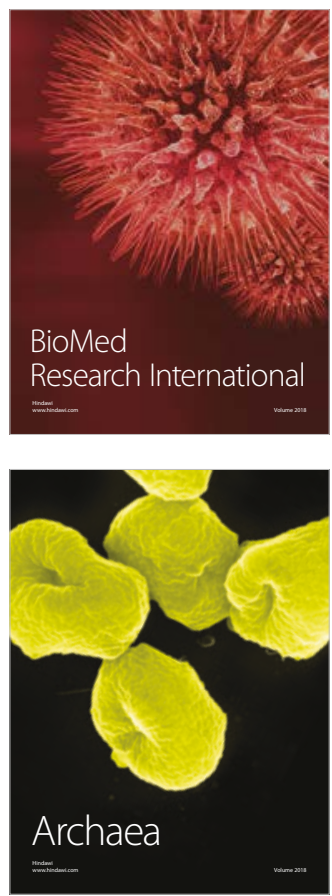